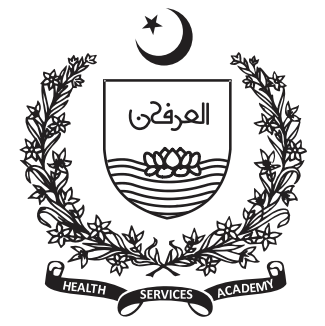

1FMH College of Medicine and Dentistry, Lahore,

Pakistan

${ }^{2}$ College of Earth and

Environmental Sciences, University of the Punjab,

Lahore, Pakistan

3Sustainable Development Study Centre, Government College University, Lahore, Pakistan

Corresponding Author: Muhammad Maaz Arif E-mail: maazarifbutt@gmail.com

\section{Occupational Stress among Medical and Paramedical Staff in Tertiary Care Hospitals Based on Observational Study}

Muhammad Maaz Arif1,2, Abdul Qadir2, Sajid Rashid Ahmad², Mujtaba Baqir $^{2,3}$, Muhammad Irfan ${ }^{2}$

\section{Abstract}

Background: Occupational stress is a common concern among employees, particularly those working in tertiary care hospitals. In Pakistan, both medical and paramedical staffs face many stressors because of their high job demand, dealing with multiple patients, excessive duty hours, and strict rules and regulations. The objective of the study was to measure occupational stress among the tertiary care hospital employees of the Lahore District using different demographic and workplace determinants.

Methods: It was a cross-sectional study. A total of 138 hospital employees recorded their responses, which included 71 medical staff/doctors and 67 paramedical staff members. Primary data was obtained through a detailed structured questionnaire based on the Likert scale with the stress level index ranging from 1-5.

Results: In terms of the six staff designations, stress index from top to bottom was observed in house officers/ internees (3.47), medical officers/ postgraduate trainees (3.04), technicians (2.74), consultants/ specialists (2.73), emergency/ ward assistants (2.61) and nurses (2.46). Among all the employees, the most significant factors leading to stress bottom-down were justice/ fairness (3.30), tasks and roles (3.14), management (3.03), environment/ working conditions (3.01), decision-making autonomy (2.84), work schedule (2.62) and profession/ job entitlement (1.63). Analysis of demographic characteristics showed that males (2.99) faced greater stress than females (2.64) and people of young age group ( $\leq 30$ years) showed the highest stress value (3.01) than other age groups. It was observed that moderately experienced (5-10 years) employees were more prone to occupational stress (3.03) than other groups. Furthermore, the employees of public hospitals (3.13) bear more stress than those of private hospitals (2.67). On the basis of locality, the locals showed slightly higher stress values (2.89) as compared to non-locals (2.77).

Conclusion: The current study showed that occupational stress is a prevalent problem in hospitals, particularly among house officers and postgraduate residents. Several useful steps can be undertaken to improve the health and safety of hospital employees like alleviating duty hours, working in shifts, focusing on a single task, and motivating the employees in decision-making.

Keywords: Stress, Occupational Stress, Stressors, Hospital Employees, Resident, Paramedics. 


\section{Introduction}

$\mathrm{T}$

he working conditions inside a hospital are complex and demanding. It can create significant health and safety risks to medical and paramedical staff. The impact of poor occupational health and safety is felt not only by affected hospital employees but also by the patients they are managing. For better patient care and creating a healthy working environment, the health of hospital employees is of prime importance (1).

Stress is commonly defined as an uninvited response people have to severe pressures or other types of demands placed upon them (2). According to the American Psychiatric Association (3), stress is defined as "a sense of being overwhelmed, worried, defeated, pressed, exhausted and lethargic". Han Selye defined stress as "nonspecific response of the body to any demand" (4). Lazarus and Folkman defined it as "a particular relationship between the person and the environment that is appraised by the person as taxing or exceeding his or her resources and endangering his or her well-being" (5). Baum described it as a negative behavioral, emotional, and biological response to a perceived threat $(6,7)$.

Occupational stress is defined as a work-related disorder resulting from a combination of exposure to work demands, environmental stressors, internal stressors, and inadequate coping cum adaptive skills (5). Beehr and Newman defined job stress as a situation emerging from the interaction of people and their jobs and characterized by changes within people that force them to deviate from their normal functioning (6). Occupational stress arises due to negative biological and psychological effects related to work when high workload and pressures outweigh the person's ability to cope with stress factors at work. In terms of categorizing stress in a working environment, occupational stress can be classified as a chronic type of stress that can be both physiological or psychosocial. It is mostly related to a negative influence on an individual causing much distress. For the past few years, occupational stress is turning out to be a global problem and it is increasing gradually, especially in the United States of America and also in those nations where the industries are developing fast. Poor salaries, longer duty timings, and the negative behavior of the employers are the main factors of instilling a stressful environment in the workplace.
Occupational stress creates a lot of undesirable effects at both the individual and organizational levels. The incidents of hypertension and cardiac diseases are the main problems that are closely related to stress. India, China, Turkey, Brazil, Russia, and other Eastern European countries are the emerging countries where the stressful environment is ever-increasing. Occupational stress causes both direct and indirect costs to the employees and the organization (10). Monetary cost is required to restore the health and productivity of the worker, while absenteeism is restored by non-monetary costs. Throughout the lifespan of an individual, the period of a job has become highly important because it is directly linked to stress. Occupational stress and psychological problems are becoming the key parts of study at the workplace in almost every institution (7).

Employee satisfaction has an immensely important place in any institution. Employee job satisfaction is closely linked to their behavior and attitude at the workplace (8). Many important factors such as workload, administration, and work environment help in determining how satisfying or stressful the work can be and its harmful effects on employee's condition $(9,10)$. The four main stressrelated factors are work conflicts, inefficient resources, work overload, and work ambiguity. This measure was designed by Kahn, Wolfe, Quinn, and Snoek (11). According to a recent study highlighting occupational stress, the following 10 work-related stressors were recognized: unemployment, job insecurity, high job demands, long working hours, exposure to shift work, low social support at work, work-family conflict, lack of health insurance, low job control and low organizational justice (12). According to Rose (2003), employees have stressful trends regarding long duty hours, unfriendly environment, and heavy workload, which decreases employee's motivation for performing better (13). Management support and assistance from organizations help in reducing workrelated stress in workers. One of the reasons recognized by Stamper \& Johlke (2003) is that, if the organization does not value their employees for their good works, this may lead to stress and mostly creates the urge to quit (14). Ivancevich and Donnelly (1975) studied the relationship of stress and anxiety with employees' performance and satisfaction. At different levels of management, they found out that lower stress anxiety levels seemed to improve the performance of 
workers (15). Beehr et al., (2000) also reported that occupational stress affected the employees psychologically and decreased their performance at work (16). According to Anderson et al., (2002) family conflicts are also a predisposing factor for creating stress in employees during work (17).

In the United Kingdom, the estimated recurrence of stress and stress-related problems increased from 829 cases per 100,000 employees in 1990 to 1700 per 100,000 in 2001-2002. The Mental Health Foundation reports that in the United Kingdom (UK), about 64\% of people who are employed have common mental health problems, estimating to 4.6 million and equating to 1 in every 6.8 people at work relating to mental health issues. In working-age adults (16-64 years), the occupation was also associated with selfharm, suicidal thoughts, and suicidal attempts (18). The Health and Safety Executive (HSE) analysis of self-reported illnesses rate showed that stress, depression, or anxiety affects $1.3 \%$ of the workers (19, 20). The European Agency for Safety and Health at work cited that approximately $50 \%$ of job absenteeism is brought about by stress (21). According to The Centre for Disease Control and Prevention, about 1 in 5 US adults aged 18 or older reported any mental ailment in the year 2016. (22) According to the American Psychological Association (APA) survey conducted in 2017, work-related stress was found to be the third major source of stress in Americans.

In Pakistan, the patients who visit outpatient mental health departments are mostly identified with neurotic/ stress-related/ somatoform disorders (33\%) and mood disorders (30\%). Although a national mental health authority is present which helps the government on mental health issues, its services are not organized in terms of catchment areas. There are 3729 outpatient mental health facilities available in Pakistan out of which only $1 \%$ is available for children/ pubescent. About 343.34 patients are treated per 100,000 people. $46 \%$ of follow-up care is provided by the outpatient department (OPD) facilities while only about $1 \%$ has mental health mobile teams. In terms of occupational and mental health, health service indicators are quite low. The human resources are very low with only 203.07 mental health workers per 100,000 people (23) (Table 1).
Table 1. Categorization of Mental Health Professions in Pakistan

\begin{tabular}{|l|l|l|l|}
\hline \multicolumn{1}{|c|}{ CATEGORY } & VALUE & $\begin{array}{c}\text { PERCE } \\
\text { NTAGE }\end{array}$ & $\begin{array}{c}\text { PER } \\
\mathbf{1 0 0 , 0 0 0} \\
\text { PEOPLE }\end{array}$ \\
\hline Doctors & 25,782 & 17.67 & 15.37 \\
\hline Nurses & 13,643 & 9.34 & 8.13 \\
\hline Social Workers & 3,145 & 2.15 & 1.87 \\
\hline Psychologists & 478 & 0.33 & 0.28 \\
\hline Psychiatrists & 342 & 0.23 & 0.20 \\
\hline $\begin{array}{l}\text { Occupational } \\
\text { Therapists }\end{array}$ & 22 & 0.02 & 0.01 \\
\hline $\begin{array}{l}\text { Other Mental } \\
\text { Health Workers* }\end{array}$ & 102,597 & 70.27 & 61.15 \\
\hline Total & $\mathbf{1 4 6 , 0 0 9}$ & $\mathbf{1 0 0 . 0 0}$ & $\mathbf{2 0 3 . 0 7}$ \\
\hline
\end{tabular}

* These include auxiliary staff, primary health care workers, medical/ health assistants and professional counselors

Source: World Health Organization, (2009)

Stress at the workplace, particularly in healthcare organizations has been a concern for many decades. Different people feel stress differently in several fields of study and in different organizations. There are many doctors, nurses, and health-care assistants working at tertiary care hospitals. In the current scenario, studying the work-related stressors in hospitals is of utmost importance. This study will help in getting apprehension about the different issues and problems faced by hospital staff at tertiary care hospitals and will discuss in detail about the different stress factors affecting them. One of the challenges faced during the study was the collection of data, as many participants were reluctant in giving the interview at first possibly owing to confidential issues and their busy schedules. Another major concern faced was taking accurate information from hospital employees because of the lack of understanding, especially from lower staff and influencing factors, like the mood of participants at the time of interview or fear of revealing information about hospital administration. The aims and objectives of the current study are to determine occupational stress in medical and paramedical staff in accordance with their demographic profile, workplace determinants, and various stress factors influencing work. 
Occupational Stress among Medical and Paramedical staff in Tertiary care Hospitals based on Observational Study

\section{Methodology}

The research methodology includes study design, study setting, sources of data, participants, data collection procedure, sample size, sampling technique, the structure of the questionnaire, classification of stress determinants, and data analysis.

\section{Study Design and Setting}

It was an observational study having a cross-sectional study design, conducted at two well-established hospitals, Fatima Memorial Hospital (Private) and Services Hospital (Public) in Lahore, Pakistan. The duration of the study was about 6 months from September 2019 to January 2020.

\section{Sources}

The data collection source was primary and it was collected by a face-to-face interview from medical and paramedical staff members working at different designations.

\section{Data Collection Tools}

A detailed structured questionnaire using the Likert Scale was used to collect data. Stress levels were evaluated on a scale ranging from 1 to 5 . A stress level index was used to estimate a level that is complementary to the Depression Anxiety Stress Scale (DASS) index (0-21) (Table 2). Oral informed consent was obtained from all the respondents and a face-toface interview was conducted.

\section{Subjects / Participants}

Medical doctors and Paramedical employees working in tertiary care hospitals with all designations included from both staff types.

\section{Sample Size}

The sample drawn from the medical and paramedical staff was 148. Even though many participants were hesitant at first, however, upon multiple requests, 138 out of 148 answered the questionnaire which included 20 consultants/ specialists, 22 medical officers/ postgraduate trainees, 29 house-officers/ internees, 26 nurses, 21 technicians and 20 emergency/ ward assistants. Only 10 participants refused to answer the questionnaire, showing an overall healthy response rate $(93 \%)$. (Table 3$)$.

\section{Sampling Technique}

A stratified random sampling technique was adopted, so that all the categories of staff may be included in the sample.
Table 2. Classification of stress levels using DASS Stress Index (24)

\begin{tabular}{|l|l|l|}
\hline $\begin{array}{l}\text { STRESS } \\
\text { LEVEL }\end{array}$ & $\begin{array}{l}\text { DASS STRESS } \\
\text { INDEX (0-21) }\end{array}$ & $\begin{array}{l}\text { STRESS INDEX } \\
\text { USED (1-5) }\end{array}$ \\
\hline Normal & $0-7$ & $1.00-1.90$ \\
\hline M1ld Stress & $8-10$ & $1.91-2.38$ \\
\hline $\begin{array}{l}\text { Moderate } \\
\text { Stress }\end{array}$ & $11-13$ & $2.39-3.10$ \\
\hline $\begin{array}{l}\text { Severe Stress } \\
\text { Very Severe } \\
\text { Stress }\end{array}$ & $14-16$ & $3.11-4.05$ \\
\hline
\end{tabular}

Source: Rao \& Ramesh, (2015)

Table 3. Sample Size and Frequency of Different Professions Investigated for Stress Identification

\begin{tabular}{|l|l|l|l|}
\hline $\begin{array}{l}\text { TYPE OF } \\
\text { PROFESSI } \\
\text { ONS }\end{array}$ & $\begin{array}{l}\text { SR. } \\
\text { NO. }\end{array}$ & $\begin{array}{l}\text { DESIGNATIO } \\
\text { N }\end{array}$ & $\begin{array}{l}\text { RESPONDE } \\
\text { NTS }\end{array}$ \\
\hline \multirow{2}{*}{$\begin{array}{l}\text { Medical } \\
\text { Staff }\end{array}$} & 2. & $\begin{array}{l}\text { Consultants/ } \\
\text { Specialists }\end{array}$ & 20 \\
\cline { 2 - 4 } & 2. & $\begin{array}{l}\text { Medical } \\
\text { Officers/ } \\
\text { Postgraduate } \\
\text { Trainees }\end{array}$ & 22 \\
\cline { 2 - 4 } & 3. & $\begin{array}{l}\text { House-officers/ } \\
\text { Internees }\end{array}$ & 29 \\
\hline \multirow{2}{*}{$\begin{array}{l}\text { Paramedics } \\
\text { and Allied } \\
\text { Staff }\end{array}$} & 5. & Nurses & 26 \\
\cline { 2 - 4 } & 5. & $\begin{array}{l}\text { Technicians } \\
\text { Emergency/ }\end{array}$ & 21 \\
\cline { 2 - 4 } & 6 & 138 \\
\hline \multicolumn{2}{|l}{ Total Respondents } & 20 \\
\hline
\end{tabular}




\section{Questionnaire Structure}

A detailed questionnaire was formulated consisting of 35 questions divided into 7 sections, each section relating to a stress factor. The type of scale used was the Likert scale.

\section{Classification of Stress Determinants}

In terms of determinants related to occupational stress, these were divided into demographic determinants, workplace determinants, and various factors or stressors involving occupation. Demographic determinants included gender, age, and locality. Workplace determinants were divided into work experience and type of organization. There were seven different factors on which stress levels were evaluated; these comprised of tasks/roles, profession/job entitlement, work schedule, decision-making autonomy, environment/working conditions, management, and justice/fairness.

\section{Data Analysis}

Data analysis was computed using SPSS software. For qualitative variables like gender and locality, frequencies and percentages were used whereas for quantitative variables like age, averages and mean deviations were calculated.

\section{Results}

The results of the study included demographic profile, workplace determinants, and their association with occupational stress. It also depicted different factors influencing occupational stress both at individual and combined levels.

\section{Demographic Profile}

The study samples included $64.49 \%$ male $(n=89)$ and $35.51 \%$ female $(n=49)$ hospital employees. In terms of mean and mean deviation for age, the average age was $30.86 \pm 6.48$ years for the male employees whereas $31.94 \pm 8.50$ years for the female employees. Majority of the employees were from age group $\leq 30(n=82$; $59.42 \%)$, followed by age group 31-40 ( $n=34$; $24.64 \%)$, age group $41-50(n=17 ; 12.32 \%)$ and lowest number belonged to age group $>50(n=5 ; 3.62 \%)$. It was also observed that the majority of the employees were locals $(n=95 ; 68.84 \%)$ as compared to non-locals $(n=43 ; 31.16 \%)$ (Table 4$)$.

\section{Workplace Determinants}

Majority of the employees had low experience of $<5$ years $(n=67 ; 48.55 \%)$, followed by those having high experience of $>10$ years $(n=45 ; 32.61 \%)$ and finely those with moderate experience of 5-10 years $(n=26$; $18.84 \%)$. The proportion of the data taken from private and public hospitals was fairly even including $56.52 \%$ $(n=78)$ from private sector and $43.48 \%(n=60)$ from public sector (Table 5).

Table 4. Categorization of Medical and Paramedical staff according to Age, Gender and Locality during the Survey

\begin{tabular}{|c|c|c|c|c|c|}
\hline \multirow{4}{*}{$\begin{array}{c}\text { VARIA } \\
\text { BLES }\end{array}$} & $\begin{array}{c}\text { CATEG } \\
\text { ORY }\end{array}$ & $\begin{array}{c}\text { MEDI } \\
\text { CAL } \\
\text { STAFF }\end{array}$ & $\begin{array}{c}\text { PARA } \\
\text { MEDI } \\
\text { CAL } \\
\text { STA } \\
\text { F }\end{array}$ & $\begin{array}{c}\text { OV } \\
\text { ER } \\
\text { ALL } \\
\text { STA } \\
\text { FF }\end{array}$ & $\begin{array}{c}\text { PERCE } \\
\text { NTAG } \\
\text { E }\end{array}$ \\
\hline \multirow{4}{*}{ Age } & $\leq 30$ & 48 & 34 & 82 & $59.42 \%$ \\
\cline { 2 - 6 } & $31-40$ & 14 & 20 & 34 & $24.64 \%$ \\
\cline { 2 - 6 } & $41-50$ & 7 & 10 & 17 & $12.32 \%$ \\
\cline { 2 - 6 } & $>50$ & 2 & 3 & 5 & $3.62 \%$ \\
\hline $\begin{array}{c}\text { Average } \\
\text { Age } \pm \\
\text { Mean } \\
\text { Deviatio } \\
\mathbf{n}\end{array}$ & All & $30.65 \pm$ & $31.91 \pm$ & 31.2 & $6 \pm$ \\
\hline \multirow{2}{*}{\begin{tabular}{c} 
Gender \\
\cline { 2 - 6 }
\end{tabular}} & Males & 48 & 41 & 89 & $100 \%$ \\
\cline { 2 - 6 } & Females & 23 & 26 & 49 & $35.51 \%$ \\
\hline \multirow{2}{*}{\begin{tabular}{c} 
Locality \\
\cline { 2 - 6 }
\end{tabular}} & Locals & 49 & 46 & 95 & $68.84 \%$ \\
\cline { 2 - 6 } & $\begin{array}{c}\text { Non- } \\
\text { Locals }\end{array}$ & 22 & 21 & 43 & $31.16 \%$ \\
\hline
\end{tabular}

Table 5. Categorization of Medical and Paramedical staff in Context to Work Experience and Organization

\begin{tabular}{|c|c|c|c|c|c|}
\hline $\begin{array}{c}\text { VARIAB } \\
\text { LES }\end{array}$ & $\begin{array}{c}\text { CATE } \\
\text { GORY }\end{array}$ & $\begin{array}{c}\text { MEDICAL } \\
\text { STAFF }\end{array}$ & $\begin{array}{c}\text { PARAMED } \\
\text { ICAL } \\
\text { STAFF }\end{array}$ & $\begin{array}{c}\text { OVER } \\
\text { ALL } \\
\text { STAFF }\end{array}$ & $\begin{array}{c}\text { PERCE } \\
\text { NTAG } \\
\text { E }\end{array}$ \\
\hline \multirow{2}{*}{$\begin{array}{c}\text { Work } \\
\text { Experien } \\
\text { ce }\end{array}$} & $\begin{array}{c}\text { ST } \\
\text { years }\end{array}$ & 39 & 28 & 67 & $48.55 \%$ \\
\cline { 2 - 6 } & $\begin{array}{c}\text { years } \\
\text { years }\end{array}$ & 13 & 13 & 26 & $18.84 \%$ \\
\hline \multirow{2}{*}{$\begin{array}{c}\text { Organiza } \\
\text { tion }\end{array}$} & $\begin{array}{c}\text { Privat } \\
\text { e }\end{array}$ & 40 & 38 & 78 & $32.61 \%$ \\
\cline { 2 - 6 } & Public & 31 & 29 & 60 & $43.48 \%$ \\
\hline
\end{tabular}

\section{Demographic Determinants Related to Occupational} Stress

Analysis of demographic characteristics showed that males faced greater stress with a stress index of 2.99 (moderate stress) than females with 2.64 (moderate 
Occupational Stress among Medical and Paramedical staff in Tertiary care Hospitals based on Observational Study

stress). The same pattern was indicated separately for medical staff and paramedical staff. Males from medical staff showed a stress index of 3.27 (extreme stress) as compared to females showing 2.85 (moderate stress), whereas males from paramedical staff showed a stress index of 2.67 (moderate stress) than females showing 2.46 (moderate stress). As far as age is concerned, employees of age group $\leq 30$ years showed the most stress value with an index of 3.01 (moderate stress) than other age groups. For medical staff, the stress value was highest for age group $\leq 30$ years with an index of 3.36 (extreme stress), whereas for paramedical staff it was highest for age group 3140 with an index of 2.84 (moderate stress). For locality, results displayed that locals showed a slightly higher stress value of 2.89 (moderate stress) as compared to non-locals with 2.77 (moderate stress). (Table 6).

Table 6. Demographic Stress scores for Medical/Paramedical Profession Categories on basis of Gender, Age and Locality

\begin{tabular}{|c|c|c|c|c|c|c|c|c|}
\hline \multirow{3}{*}{$\begin{array}{l}\text { HOSPITAL } \\
\text { EMPLOYEE } \\
S\end{array}$} & \multicolumn{8}{|c|}{ STRESS SCORES } \\
\hline & \multicolumn{2}{|c|}{ GENDER } & \multicolumn{4}{|c|}{ AGE } & \multicolumn{2}{|c|}{$\begin{array}{c}\text { LOCALIT } \\
\text { Y }\end{array}$} \\
\hline & $\begin{array}{c}\text { MAL } \\
\text { ES }\end{array}$ & $\begin{array}{c}\text { FEMA } \\
\text { LES }\end{array}$ & $\begin{array}{c}\mathrm{AG} \\
\mathrm{E} \leq \\
30\end{array}$ & $\begin{array}{c}\text { AG } \\
\text { E } \\
31- \\
40 \\
\end{array}$ & $\begin{array}{c}\text { AG } \\
\text { E } \\
41- \\
50 \\
\end{array}$ & $\begin{array}{l}\text { AGE } \\
>50\end{array}$ & $\begin{array}{c}\text { Loc } \\
\text { al }\end{array}$ & $\begin{array}{c}\text { No } \\
\text { n- } \\
\text { Loc } \\
\text { al } \\
\end{array}$ \\
\hline $\begin{array}{l}\text { Consultants } \\
\text { / Specialists }\end{array}$ & 3.04 & 2.27 & $\begin{array}{c}2.4 \\
0\end{array}$ & $\begin{array}{c}2.9 \\
3\end{array}$ & $\begin{array}{c}2.4 \\
2\end{array}$ & 3.16 & 2.78 & 2.64 \\
\hline $\begin{array}{c}\text { Medical } \\
\text { Officers/ } \\
\text { Postgraduat } \\
\text { e Trainees }\end{array}$ & 3.03 & 3.08 & $\begin{array}{c}3.2 \\
6\end{array}$ & $\begin{array}{c}2.0 \\
9\end{array}$ & $\begin{array}{c}\mathrm{N} / \\
\mathrm{A}\end{array}$ & N/A & 2.88 & 3.40 \\
\hline $\begin{array}{c}\text { House- } \\
\text { officers/ } \\
\text { Internees }\end{array}$ & 3.57 & 3.23 & $\begin{array}{c}3.4 \\
7\end{array}$ & $\begin{array}{c}\mathrm{N} / \\
\mathrm{A}\end{array}$ & $\begin{array}{c}\mathrm{N} / \\
\mathrm{A}\end{array}$ & N/A & 3.43 & 3.55 \\
\hline $\begin{array}{c}\text { TOTAL } \\
\text { MEDICAL } \\
\text { STAFF } \\
\end{array}$ & 3.27 & 2.85 & $\begin{array}{c}3.3 \\
6\end{array}$ & $\begin{array}{c}2.6 \\
9\end{array}$ & $\begin{array}{c}2.4 \\
2\end{array}$ & 3.16 & 3.09 & 3.21 \\
\hline Nurses & N/A & 2.46 & $\begin{array}{c}2.5 \\
6\end{array}$ & $\begin{array}{c}2.5 \\
4\end{array}$ & $\begin{array}{c}2.0 \\
8\end{array}$ & 2.00 & 2.70 & 1.92 \\
\hline Technicians & 2.73 & N/A & $\begin{array}{c}2.3 \\
8\end{array}$ & $\begin{array}{c}3.0 \\
4\end{array}$ & $\begin{array}{c}2.9 \\
7\end{array}$ & 3.00 & 2.80 & 2.60 \\
\hline $\begin{array}{l}\text { Emergency/ } \\
\text { Ward } \\
\text { Assistants }\end{array}$ & 2.61 & N/A & $\begin{array}{c}2.5 \\
8\end{array}$ & $\begin{array}{c}2.8 \\
7\end{array}$ & $\begin{array}{c}2.2 \\
9\end{array}$ & 2.20 & 2.50 & 2.46 \\
\hline $\begin{array}{c}\text { TOTAL } \\
\text { PARAMED } \\
\text { ICAL } \\
\text { STAFF } \\
\end{array}$ & 2.67 & 2.46 & $\begin{array}{c}2.5 \\
2\end{array}$ & $\begin{array}{c}2.8 \\
4\end{array}$ & $\begin{array}{c}2.4 \\
1\end{array}$ & 2.40 & 2.67 & 2.30 \\
\hline $\begin{array}{c}\text { OVERALL } \\
\text { STAFF }\end{array}$ & 2.99 & 2.64 & $\begin{array}{c}3.0 \\
1\end{array}$ & $\begin{array}{c}2.7 \\
8\end{array}$ & $\begin{array}{c}2.4 \\
1\end{array}$ & 2.70 & 2.89 & 2.77 \\
\hline
\end{tabular}

\section{Workplace Determinants Related to Occupational Stress}

Data showed that moderate experienced (5-10 years) employees were more sensitive to stress at work than other groups with a stress score of 3.02 (moderate stress). For medical staff, workers with less experience ( $<5$ years) showed the most stress with an index of 3.35 (severe stress), whereas for paramedical staff workers with moderate experience showed the most stress with an index of 2.89 (moderate stress). Data also showed that the employees of the public hospital with an index of 3.13 (severe stress) were more sensitive to stress than those working in the private hospital showing an index of 2.67 (moderate stress). The same pattern was seen for medical staff in the public sector showing a greater stress index with 3.47 (severe stress) as compared to paramedical staff in the public sector showing an index of 2.76 (moderate stress). (Table 7).

\section{Factors Related to Occupational Stress}

As far as factors related to occupational stress is concerned, the study presented that on basis of all the evaluated factors the medical staff revealed greater stress with an index of 3.13 (severe stress) than paramedical staff with 2.59 (moderate stress) whereas overall staff showed stress index of 2.87 (moderate stress). In terms of the six staff designations, the prevalence of stress index from highest to lowest was observed among house officers/ internees (3.47), medical officers/ postgraduate trainees (3.04), technicians (2.74), consultants/ specialists (2.73), emergency/ ward assistants (2.61) and nurses (2.46) (Figure 1). For all employees, the most significant factors leading to stress from top to bottom were justice/ fairness (3.30), tasks and roles (3.14), management (3.03), environment/ working conditions (3.01), decision-making autonomy (2.84), work schedule (2.62) and profession/ job entitlement (1.63). For medical staff most significant factors bottom-down were tasks and roles (3.40), working conditions (3.38), management (3.35), justice (3.31), work schedule (3.04), decision making autonomy (2.94), and job entitlement (1.91) whereas for paramedical staff significant factors highest to lowest were justice (3.29), tasks and roles (2.87), decision making autonomy (2.73), management (2.68), working conditions (2.62), work schedule (2.18) and job entitlement (1.34) (Table 8). 
Table 7. Workplace Determinants Related to Occupational Stress among Different Medical/Paramedical Profession Categories on basis of Work Experience and Organization

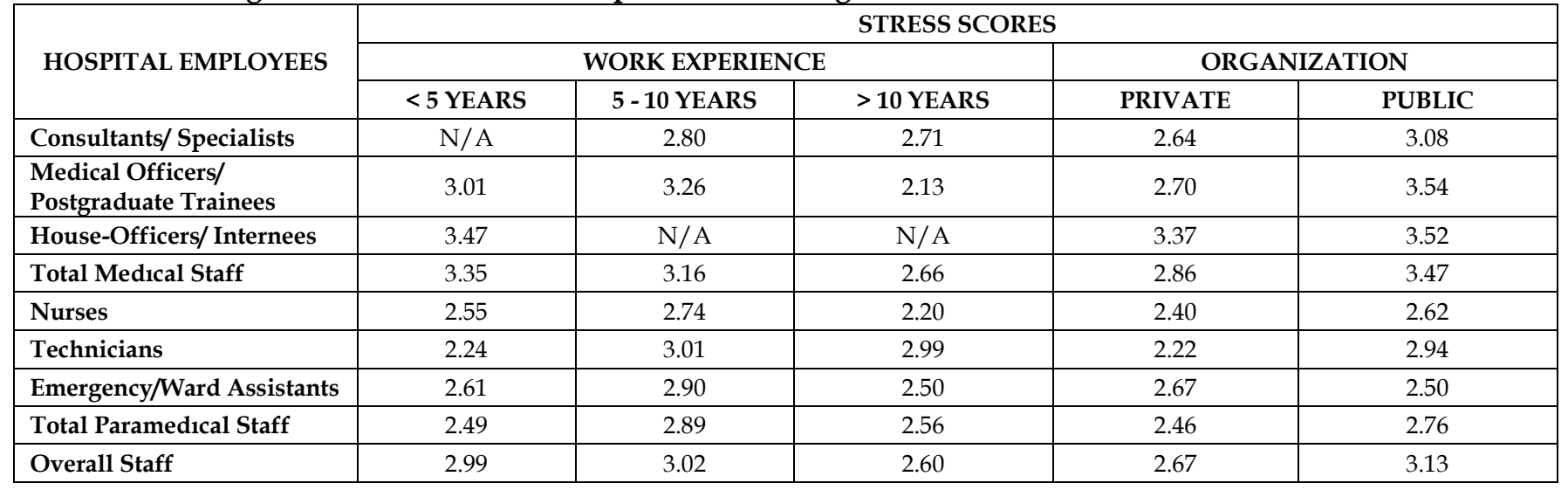

Table 8. Factors Related to Occupational Stress among Different Medical/Paramedical Profession Categories

\begin{tabular}{|l|c|c|c|c|c|c|c|c|}
\hline \multirow{2}{*}{$\begin{array}{c}\text { HOSPITAL } \\
\text { EMPLOYEES }\end{array}$} & $\begin{array}{c}\text { TASKS } \\
\text { AND } \\
\text { ROLES }\end{array}$ & $\begin{array}{c}\text { PROFESSI } \\
\text { ON/JOB } \\
\text { ENTITLE } \\
\text { MENT }\end{array}$ & $\begin{array}{c}\text { WORK } \\
\text { SCHEDUL } \\
\text { E }\end{array}$ & $\begin{array}{c}\text { DECISION } \\
\text { MAKING } \\
\text { AUTONO } \\
\text { MY }\end{array}$ & $\begin{array}{c}\text { ENVIRONME } \\
\text { NT/ } \\
\text { WORKING } \\
\text { CONDITIONS }\end{array}$ & $\begin{array}{c}\text { MANAGE } \\
\text { MENT }\end{array}$ & $\begin{array}{c}\text { JUSTICE/ } \\
\text { FAIRNESS }\end{array}$ & $\begin{array}{c}\text { ALL } \\
\text { FACTORS }\end{array}$ \\
\hline $\begin{array}{l}\text { Consultants/ } \\
\text { Specialists }\end{array}$ & 3.14 & 1.51 & 1.93 & 2.63 & 2.80 & 3.15 & 3.20 & 2.73 \\
\hline $\begin{array}{l}\text { Medical } \\
\text { Officers/ } \\
\text { Postgraduate } \\
\text { Trainees }\end{array}$ & 3.25 & 2.13 & 2.81 & 2.86 & 3.45 & 3.26 & 3.06 \\
\hline $\begin{array}{l}\text { House-Officers/ } \\
\text { Internees }\end{array}$ & 3.70 & 2.02 & 3.97 & 3.21 & 3.72 & 3.57 & 3.57 \\
\hline $\begin{array}{l}\text { Total Medical } \\
\text { Staff }\end{array}$ & 3.40 & 1.91 & 3.04 & 2.94 & 3.38 & 3.35 & 3.31 \\
\hline Nurses & 2.61 & 1.26 & 2.51 & 2.35 & 2.55 & 2.55 & 3.08 & 3.47 \\
\hline Technicians & 3.06 & 1.40 & 1.77 & 3.14 & 2.97 & 2.77 & 3.57 & 2.47 \\
\hline $\begin{array}{l}\text { Emergency/ } \\
\text { Ward } \\
\text { Assistants }\end{array}$ & 3.00 & 1.38 & 2.19 & 2.80 & 2.34 & 2.74 & 3.29 \\
\hline $\begin{array}{l}\text { Total } \\
\text { Paramedical } \\
\text { Staff }\end{array}$ & 2.87 & 1.34 & 2.18 & 2.73 & 2.62 & 2.68 & 3.29 \\
\hline Overall Staff & 3.14 & 1.63 & 2.62 & 2.84 & 3.01 & 3.03 & 3.30 \\
\hline
\end{tabular}




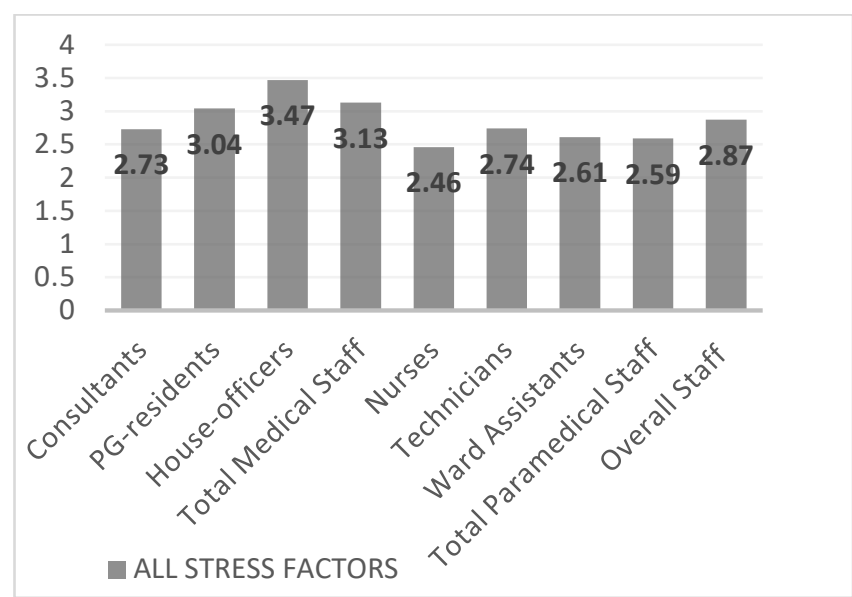

Figure 1: Graph showing Occupational Stress among Different Medical/Paramedical Professions on basis of All Stress Factors

From the results gathered, it was observed that medical staff members suffered greater from workrelated stress than paramedical staff members. Among the medical staff, the employees who suffered the most from job stress were mainly house-officers and postgraduate trainees. The issues of job stress in hospital employees can be alleviated by following some managerial implications like clearly defining tasks and roles for each employee, alleviating duty hours, working in shifts (including morning, evening, and night shifts), proper in-place leave code and replacement rules, hiring more staff to meet the demand of hospital services, monitoring staff turnover rate and creating a clean and healthy environment for the workplace. Newly inducted hospital employees should have proper orientation and knowledge about their tasks and duties. Bullying from senior staff members should be discouraged; seniors should create opportunities among lower staff to participate in problem-solving skills and maintaining discipline during work.

\section{Discussion}

The study showed similarity to other researches in various aspects when it came to employees suffering from job stress in the hospital environment. The current study showed an average age of all the employees to be 31.94 similar to 28.68 in a study by Syeda et al., (2019) (25). It also showed that among medical staff, house officers and postgraduate residents suffered the most from job stress again showing similarity to a study by Syeda et al., (2019) (25). Apart from different stress factors faced by house officers and postgraduate residents, other reasons include hierarchical bashing by seniors, direct involvement with patients, lack of support by staff members, and lack of unity. The study showed that workers from age $\leq 30$ with low working experience were higher in proportion than other groups similar to studies done by Chou et al., (2014) and Al-Hussein (2009) (26, 27). Results also showed that private hospital employees were less sensitive to stress than government hospital employees similar to a study done by Battu (2014); this is owing to different stress factors discussed in Table 8, sub-standard service structure, and poor health service indicators of many public hospitals in Pakistan (28).

The study showed disparity when it came to male and female proportions among hospital employees. The current study indicated male proportion to be higher $(64.49 \%)$ than females and also showed the relationship of stress to be higher in males, dissimilar to study done by Chou et al., (2014), which showed a higher proportion of females $(82.8 \%)$ and also showed job stress associated higher with females. The main stress factors for males included lack of justice/ fairness, poor management, and stressful tasks while other reasons are that, males have greater job responsibility, are more prone to bullying by seniors, they often look for a second job (e.g, private practices), and are involved in family tasks and responsibilities. The results showed that the group most affected by stress was house officers/ internees different from a research conducted by Chou et al., (2014) showing the nursing group to be most affected by stress (26). The opposite trend is due to the main differences among the stress factors associated with work schedule, tasks/ roles, and management; other reasons showed that nursing group usually work together more cohesively than any other group and as many of them have a relatively better experience and relations with other employees, their work schedule, duties and roles are better defined, whereas house officers are fresh workers/trainees and suffer greatly from poorly defined roles, hierarchical advantage from seniors and greater clerical work. The study also showed that young age group ( $\leq 30$ years) suffered the most from stress. The stress factors showed work schedule, decision-making autonomy, and stressful tasks/ roles to stand out in this group; other reasons include bullying by seniors, lack of proper orientation 
for new workers, and no support from administrative staff. It was also shown that among paramedics and allied staff, technicians faced the most stress contrary to research done by Al-Hussain (2009), showing the nursing group to be most affected by stress (27). The factors that were the main difference were lack of decision-making autonomy, lack of justice/ fairness, and stressful tasks; another possible reason is that the nursing group is more cohesive and have a hierarchical advantage over both technicians and ward boys. Besides, with the advent of greater reliance on laboratory tests for diagnosis, the duty of technicians has become quite burdensome, also, they are more prone to infections, accidents, and needle stick injuries.

In terms of experience, the overall analysis revealed that moderately experienced employees suffered the most from stress. The factors reported highest among this group were poor management, lack of decision-making autonomy, and stressful tasks, also because moderately experienced workers are mostly medical officers/ postgraduate residents, they suffer from management issues from seniors and also have to deal with supervising tasks and roles to juniors. It was seen that public sectors faced greater stress among their employees over private sectors. The stressors that differentiated the two groups significantly were lack of justice/ fairness, poor management, and poor environment/ working conditions. The health service indicators like hospitals to patient ratio, beds to patient ratio, doctors and nurses to patient ratio are exceedingly low in public hospitals of Pakistan; as most people are from lower and middle-class, they tend to prefer public over private hospitals, so burden faced by public hospitals far outweighs their resources and is ultimately reflected in their employees. In addition, it was observed that non-locals faced slightly less stress than locals did. The differentiating factors were work schedule and lack of justice/ fairness; also, it may be due to non-locals being more acclimatized to different environments.

The comparison of this study with some of the previous works is shown in Table 9. The stress scores in the present research (Lahore, Pakistan) are compared with researches conducted in India, Iran, Northwest Ethiopia, Taiwan, and Indonesia (26, 27, 29, 30, 31). The different indices used in other studies were adjusted with the stress index used in the current work. Lowest to highest stress scores varied in different studies for designation of staff, stress factors, and confidence intervals.

Table 9: Comparison of Stress Score Indices with Previous Studies

\begin{tabular}{|c|c|c|c|}
\hline Study & $\begin{array}{c}\text { Differet } \\
\text { Stress } \\
\text { Indices } \\
\text { (Used in } \\
\text { Study) }\end{array}$ & $\begin{array}{c}\text { Adjusted } \\
\text { Stress } \\
\text { Index } \\
\mathbf{( 1 - 5 )}\end{array}$ & Reference \\
\hline $\begin{array}{c}\text { Lahore, } \\
\text { Pakistan }\end{array}$ & $\begin{array}{c}2.51-3.47 \\
(1-5)\end{array}$ & $2.51-3.47$ & Present Study \\
\hline India & $\begin{array}{c}34.0-50.0 \\
(0-100)\end{array}$ & $2.36-3.00$ & $\begin{array}{c}\text { Amte et al. } \\
(2015)\end{array}$ \\
\hline Iran & $\begin{array}{c}42.9-64.3 \\
(0-100)\end{array}$ & $2.72-3.57$ & $\begin{array}{c}\text { Al-Hussein et } \\
\text { al. (2009) }\end{array}$ \\
\hline $\begin{array}{c}\text { Northwest } \\
\text { Ethiopia }\end{array}$ & $\begin{array}{c}62.8-73.2 \\
(0-100)\end{array}$ & $3.51-3.93$ & $\begin{array}{c}\text { Birhanu et al. } \\
(2018)\end{array}$ \\
\hline Taiwan & $\begin{array}{c}31.9-66.0 \\
(0-100)\end{array}$ & $2.28-3.64$ & $\begin{array}{c}\text { Chou et al. } \\
(2014)\end{array}$ \\
\hline Indonesia & $\begin{array}{c}13.1-20.6 \\
(0-81)\end{array}$ & $1.65-2.02$ & $\begin{array}{c}\text { Putri et al. } \\
(2018)\end{array}$ \\
\hline
\end{tabular}

\section{Limitations}

There were a few limitations faced during the study. This included a thorough psychiatric and psychological analysis of the participants about how many of them may have been diagnosed with depression, anxiety, or mood disorders and how many may have been taking medications. Another important limitation in the study was a complete analysis of the rules, regulations, services, and facilities set and provided by each hospital to the patients and the employees.

\section{Conclusion}

The current research showed that occupational stress is a prevalent problem in hospitals across Pakistan, particularly among house officers and postgraduate residents. The stress index values of different designations combined with demographic profile, workplace determinants, and stress factors provided substantial contributions to the study. The problems and issues faced by hospital staff will be helpful for health-care institutions to formulate better strategies that will increase satisfaction level, maintain a healthy work-life balance and minimize job stress, consequently enhancing efficiency and working of hospitals. The results from this study can also be applied for future studies as a support for ongoing further research, reviewing it for important content. Several useful steps can be undertaken to improve the 
health and safety of hospital employees. Excessive and extra hours of work that affect worker health should be regulated. Encourage open communication of employees with supervisors and managers to deal with work-related stress. Improvements should be made in the financial structure of employees including salary benefits and advancements. Multi-task responsibilities are difficult to manage, so employees should be advised to focus on a single task at a time. Provide counseling on work-related problems. Motivate the employees to participate in decision making and thinking better ideas for dealing with difficult situations. Highlight the stress audit at all levels and find out about the reasons that increase stress in the employees and work out different methods to eliminate these reasons.

On specific issues, especially relating to houseofficers and postgraduate residents, duty hours should be regulated according to Pakistan Medical and Dental Council/Pakistan Medical Commission (PMDC/PMC) guidelines, their roles and instructions should be well defined and displayed. Multitask responsibilities should be avoided. A culture of hierarchical bullying and bashing by seniors over juniors should be amended. Seniors and juniors should work together and create a healthy, collaborative environment among all staff employees. Infections and needle stick injuries are quite common; Occupational Safety and Health Administration (OSHA) guidelines for health and safety should be observed for all health hazards affecting hospital employees. The administration should deal with all employees with equity. There should be an observance of a proper leave code and a clearly defined replacement system. An occupational therapist for workplace counseling, an occupational health specialist for analyzing work environments and procedures, and a quality management officer for overseeing staff performance and maintaining standard quality and processes should be hired in hospitals. The Federal Government, Punjab Government, Specialized Healthcare \& Medical Education Department, and Healthcare Administration are responsible for hospital resources, environment, working conditions, and health service indicators. These resources and indicators are particularly low especially in public hospitals, hence there should be a change in healthcare policies, improvement of public hospitals, and increment in spending and investment of money in healthcare budget to achieve better healthcare services.

\section{References}

1. Auditor-General, V. Occupational Health and Safety Risk in Public Hospitals. 2013.

2. GB. E. Managing The Causes Of Work-Related Stress, A Step-By-Step Approach Using The Management Standards. 2007.

3. American Psychological Association. Stress in America: The State of Our Nation. Stress in americatm Survey. 2017.

4. Bhui K, Dinos S, Galant-miecznikowska M, De jongh B, Stansfeld S. Perceptions of work stress causes and effective interventions in employees working in public, private and non-governmental organisations: a qualitative study. Bjpsych Bull, 2016; 40(6):318-325.

5. Beehr TA, Newman JE. Job stress, employee health, and organizational effectiveness: A facet analysis, model, and literature review, 1978; 31(4):665 - 699.

6. Bahrami S. Influences of Culture and Social Class on perception Of Job Stress in Emerging Economies. International Review of Business Research Papers. 2010; Volume 6. Number 2, pp.52-67.

7. Yaribeygi H, Panahi Y, Sahraei H, Johnston TP, Sahebkar A. The impact of stress on body function: A review. EXCLI J, 2017; 16:1057-1072.

8. Aziz, Imrana \& Kumar, Ramesh \& Rathore, Anita \& Lal, Manohar. WORKING ENVIRONMENT AND JOB SATISFACTION AMONG HEALTH PROFESSIONAL WORKING AT A TERTIARY CARE HOSPITAL OF PAKISTAN. Journal of Ayub Medical College, Abbottabad : JAMC. 2015; 27. 201-4.

9. Beehr TA. and Bhagat RS. "Introduction to human stress and cognition in organizations", in Beehr TA. and Bhagat RS. (Eds), Human Stress and Cognition in Organizations, Wiley, New York, NY, 1985; pp. 3-19.

10. Shaikh ZA., Noor N, Farooq A, Khaleel M, Naqvi D, Ahmed U, Ahmed H, Shakil F, Shamim J, Asif J, Khan S, \& Abbas HA. Assessing the risk factors of work-related stress among house officers of tertiary care hospitals, karachi. Pakistan Journal of Public Health, 2018; 8(2), 117-122.

11. Kahn RL., Wolfe DM, Quinn RP, Snoek JD and Rosenthal RA. Organizational Stress: Studies in Role Conflict and Ambiguity. Wiley, New York. 1964.

12. Goh J, Pfeffer J, Zenios S. The Relationship Between Workplace Stressors and Mortality and Health Costs in the United States. Management Science, 2016; 62(2), 608628.

13. Rose M. Good Deal, Bad Deal? Job Satisfaction in Occupations. Work Employment Society, 2003; 17; 503.

14. Stamper LC, \& Johlke CM. The Impact of Perceived Organizational Support on the Relationship Between Boundary Spanner Role Stress and Work Outcomes. 
Journal of Management, 2003; 29; 569.

15. Ivancevich MJ, \& Donnelly HJ. Relation of Organizational Structure to Job Satisfaction, AnxietyStress, and Performance. Administrative Science Quarterly, 1975; 20(2), pp. 272-280.

16. Beehr AT, Jex MS, Stacy AB, \& Murray AM. Work Stressors and Coworker Support as Predictors of Individual Strain and Job Performance. Journal of Organizational Behavior, 2000; 21(4), pp. 391-405.

17. Anderson ES, Coffey SB, \& Byerly TR. Formal Organizational Initiatives and Informal Workplace Practices: Links to Work-Family Conflict and JobRelated Outcomes. Journal of Management 2002; 28,787.

18. Mental Health Foundation. Fundamental Facts About Mental Health 2016. Mental Health Foundation: London. 2016.

19. Salleh MR. Life event, stress and illness. Malays J Med Sci, 2008; 15(4):9-18.

20. Self-reported work-related illness in 2001/02: Results from a household survey, (SW 101/02), HSE. 2003.

21. European Agency for Safety and Health. OSH in figures: stress at work - facts and figures. 2009.

22. Centers for Disease Control and Prevention (CDC). Mental Health In The Workplace. 2018.

23. World Health Organization. A report of the assessment of the mental health system in Pakistan using the World Health Organization - Assessment Instrument for Mental Health Systems (WHO-AIMS). 2009.

24. Rao S, Ramesh N. Depression, anxiety and stress levels in industrial workers: A pilot study in Bangalore, India.
Ind Psychiatry J, 2015; 24(1):23-8.

25. Syeda BM, Sidra G, Qurra-tul-Ain, Saifullah K. High burn out among doctors working in a tertiary care hospital; a wakeup call. Journal of the Pakistan Medical Association, 2019; 69(3).

26. Chou LP, Li CY, Hu SC. Job stress and burnout in hospital employees: comparisons of different medical professions in a regional hospital in Taiwan. BMJ Open, 2014; 4: e004185.

27. Al-Hussein RY, Al-Mteiwty AM. Point prevalence of depression, anxiety and stress amnog nurses and paramedical staff in teaching hospitals in mosul. 2009.

28. Battu N, Chakravarthy GK. Quality of work life of nurses and paramedical staff in hospitals. International Journal of Business and Administration Research Review, 2014; 2(4).

29. Amte R, Munta K, \& Gopal PB. Stress levels of critical care doctors in India: A national survey. Indian journal of critical care medicine: peer-reviewed, official publication of Indian Society of Critical Care Medicine, 2015; 19(5), 257-264.

30. Birhanu M, Gebrekidan B, Tesefa G, \& Tareke M. Workload Determines Workplace Stress among Health Professionals Working in Felege-Hiwot Referral Hospital, Bahir Dar, Northwest Ethiopia. Journal of environmental and public health, 2018; 6286010.

31. Putri LA \& Syaebani MI. Employees Work Stress Level in the Hospital. International Research Journal of Business Studies. 2018; 11. 231-243. 